\title{
SRSF Protein Kinase 1
}

National Cancer Institute

\section{Source}

National Cancer Institute. SRSF Protein Kinase 1. NCI Thesaurus. Code C102762.

SRSF protein kinase 1 ( $655 \mathrm{aa}, \sim 74 \mathrm{kDa}$ ) is encoded by the human SRPK1 gene. This protein is involved in the phosphorylation of splicing factors. 